\title{
RELATIONSHIP BETWEEN INCOME LEVEL, PERCEPTION OF HEALTH SERVICES AND CADRES'S ACTIVITY WITH COMPLIANCE WITH PAYMENT OF INDEPENDENT \\ NATIONAL HEALTH ASSURANCE IN KOLAKA DISTRICT
}

\author{
Jumiati Bandu $^{1}$, La Ode Kamalia ${ }^{2}$, Erwin Azizi Jayadipraja ${ }^{3}$ \\ ${ }^{1}$ Kolaka District Health Department \\ ${ }^{2,3}$ Magister of Public Health Study Program, Universitas Mandala Waluya \\ Kendari, Southeast Sulawesi Province, Indonesia
}

Corresponding Author : Jumiati Bandu

Email : jumiati.bandu1@ gmail.com

\begin{abstract}
Background:Every year, the social insurance administration always experiences a very large deficit. The high number of deficits experienced by the social insurance is due to the low level of compliance of contribution payments by independent participants. The purpose of this study was to determine the relationship between income levels, patient perceptions of health services and activeness of cadres with compliance with payment the Independent National Health Insurance in Kolaka District.

Methods:This research is a quantitative study with a cross sectional study approach. The population in this study were 1075 independent National Health Insurance participants. The sample size was 89 respondents who were taken by proportional random sampling. The data were obtained using a questionnaire and then analyzed descriptively and inferentially using the Chi Square test.

Results:The results showed that there was a relationship between income levels, patient perceptions of health services and the activeness of cadres with compliance with the payment of the independent national health insurance in Kolaka District, where the p-value $<\alpha=0.05$.

Conclusion:Perception of health services is the most related factor in comparison to the level of income and activity of the cadres. It is hoped that the social insurance administration organization will carry out strategies in an effort to increase the regularity or compliance of the independent national health insurance participants and increase the number of cadres.
\end{abstract}

Key words: Income, Perception, Health services, Cadre 


\section{INTRODUCTION}

Since the launch of the national health insurance program in 2014, the program's membership coverage has continued to increase. In 2014, the number of national health insurance participants was $133,400,000$ people, of which 95.1 million (72.3\%) were participants who received contribution assistance and 38.3 million (28.7\%) were noncontribution assistance recipients. In 2015, the number of participants was 156.7 million, consisting of $98,900,000(63.1 \%)$ who were participants who received contribution assistance and 57.8 million (36.9\%) were participants who were non-contributory recipients. In 2016 the number of participants increased to $171,900,000$ people, of which 106, 6,000,000 were participants who received contribution assistance and 6.5 million (38.0\%) were non-contributory participants. In 2017, the number of participants was $187,000,000$, consisting of $112,600,000$ (58.63\%) from the contribution assistance segment and 86.1 million (41. 37\%) non-contribution assistance recipients. In 2018 the number of participants increased dramatically where there were $208,100,000$ of which $122,000,000$ people (58.63\%) were participants who received contribution assistance and the remaining 86.1 million (41.37\%) were non-beneficiary participants dues. If you look at the data above, the most significant growth of participants from year to year occurs in the segment of non-contribution assistance recipients (1).

For the province of Southeast Sulawesi itself, an increase in non-contribution assistance beneficiaries also occurred, this can be seen from the health profile of Southeast Sulawesi province showing, in 2016 of the $1,582,275$ people who participated in the national health insurance, 466,022 of them were non-contributory participants who received contribution assistance. Consisting of 324,341 wage earners, 106,510 non-wage earners and 35,171 non-workers. In 2017, out of $1,820,990$ people who participated in the national health insurance, there were 531,192 people including non-contribution assistance participants consisting of 346,461 wage earners, 149,584 non-wage workers and 35,147 non-workers. In addition, in 2018 it increased quite significantly, from 2,226,751 people who participated in the national health insurance, 597.

The most significant increase occurred in the segment of non-contribution assistance recipients, which also occurred in Kolaka district, where in 2016 there were 51,292 noncontribution assistance recipients in Kolaka district. In 2017 in Kolaka district, 37782 workers received wages of 13,300 non-wage earners and 5,376 non-workers. In 2018, there was a significant increase in Kolaka district, where there were 23,605 workers who received wages as many as 12,250 workers who did not receive wages and 35855 were not workers(2).

The increase in the coverage of the non-contribution assistance beneficiary group, especially in the non-wage earning and nonworker segmentation of workers has a big health risk but with a continuous low membership contribution payment. This can be seen from the data from the social insurance administration organization, in 2014 the deficit was IDR 8.5 trillion, then in 2015 it increased by IDR 10.67 trillion, in 2016 it was IDR 11.55 trillion, in 2017 it increased significantly by IDR. 16.62 trillion, in 2018 it decreased by IDR. 10.98 trillion, and in 2019 the deficit increased again to IDR. 13 trillion. The high number of deficits experienced by social insurance administration organization is due to the low level of compliance with dues payment by independent participants.

According to a report by the social insurance administration organization at the end of 2019, the level of compliance of independent participants in paying contributions is only around $53.7 \%$, which means that around $46.3 \%$ of independent participants are not disciplined in paying dues or in arrears. Even though the total contributions from independent participants throughout 2019 reached IDR 8.9 trillion, the total claims reached IDR 27.9 trillion. This results in a large imbalance between the costs received by the social insurance administration 
organization and the costs that must be incurred. The low compliance of participants in paying contributions has resulted in the social insurance administration organization experiencing a large deficit (Social insurance administration organization (3).

This also happened in Kolaka Regency, which is one of the districts in Southeast Sulawesi Province, where according to data from the social insurance administration organization, it shows that the level of active independent participants in 2019 , on average only reached $57.79 \%$ registered independent participants. Obedient to pay dues and $42.21 \%$ of participants are in arrears, of which nearly $50 \%$ of independent national health insurance participants who are in arrears are scattered in the Kolakadistrict(3).

Several studies stated that the cause of the level of compliance of participants in paying the National Health Insurance dues was due to several things including according to research conducted on inpatients at $\mathrm{dr}$. Soebandi, Jember Regency, which states that the factors of knowledge, education, employment, availability of service places, distance to service places, ability and willingness to pay contributions, perceptions of health service places and motivation are factors related to low levels of compliance in paying contributions (1).

Research conducted on non-wage worker participants in Pacitan District shows different results, where the factors that influence contribution payment compliance are age, class of participation, participation status, utilization of First Level Health Facility services and utilization of Advanced Level Health Facility services. Contribution from participants is one source of income for the management of the health insurance scheme. Therefore, the compliance of insurance participants to pay contributions is very important for the sustainability of the health insurance scheme (2).

The results of research conducted in Denpasar City obtained information that the reason why there are still many participants in arrears is due to the payment system that uses a virtual account system, which, according to several informants, is not aware of the existence of collective family payments through virtual accounts, causing delinquent payment of dues and also some are still in arrears for payments while still using the previous system. In addition, most informants stated that they had not received direct socialization from the social insurance administration organization and had difficulties in accessing this information (3).

Other factors affecting participant compliance in making contribution payments are the level of participant's income, the number of family members insured, experience of illness. Participants who do not receive contribution assistance have a greater potential for non-compliance with paying contributions because it is different from formal sector jobs that are directly paid from salaries. Regularity in paying national health insurance contributions for independent participants is the most important component to facilitate the use of health services (4).

Based on a preliminary survey, researchers conducted interviews with four respondents who work in the social security agency for health in Kolaka Regency, it is known that the problem faced in collecting contributions from independent participants is payment arrears (not regularly paying). From the interview it was also known that the cause of the large number of participants in arrears was due to the participants' low knowledge of the importance of paying dues, this was also due to the low level of education of the participants, which resulted in the information conveyed by the social security administering agency through the information media not being properly understood. . Then, most of the arrears are class II and III maintenance participants; this is because participants usually think that they are unable to pay fees and that the government should be responsible for their contributions. The cause of the lack of compliance with the participants of the independent national health insurance is due to the lack of active cadres in providing information about the national health insurance 
in the community or the participants of the national health insurance. In addition, the number of participants was in arrears, about 2/3 arrears due to registering when they were sick and most of them had a history of catastrophic disease, then after being treated at the time of illness the participants did not make any more payments thereafter. The cause of the lack of compliance with the participants of the independent national health insurance is due to the lack of active cadres in providing information about the national health insurance in the community or the participants of the national health insurance. In addition, the number of participants was in arrears, about $2 / 3$ arrears due to registering when they were sick and most of them had a history of catastrophic disease, then after being treated at the time of illness the participants did not make any more payments thereafter. The cause of the lack of compliance with the participants of the independent national health insurance is due to the lack of active cadres in providing information about the national health insurance in the community or the participants of the national health insurance. In addition, the number of participants was in arrears, around $2 / 3$ arrears due to registering when they were sick and most of them had a history of catastrophic disease, then after being treated at the time of illness the participants did not make any more payments thereafter.

The results of the researcher interview with 10 respondents who participated in the independent national health insurance, seven (7) respondents stated that the reasons for independent participants did not regularly pay because their income was uncertain, then the fees were too high, where payments were often problematic such as automated teller machines, often offline., it takes a long time to pay because there are many queues. In addition, the remaining three (3) stated that the reason they were not compliant in making payments was that they thought that the services provided to patients using the social security administering agency were not optimal. Another reason people do not regularly pay dues is that participants feel that if they are not sick, their money will just disappear and even though they are sick, it is enough to buy medicine at the shop. In addition, the availability of a place for payment of contributions also affects respondents who do not comply, in, which the availability of a place for payment is one form of public service carried out by the government to meet community needs. The public's need for health services is a mandatory thing that must be facilitated by the government, with the existence of national health insurance and people who are obedient in paying contributions, it is hoped that the community as a whole can get health services at health facilities.

Based on the background and problem studies above, the researcher is interested in conducting research on "Determinants of Contribution Payment Compliance for Independent National Health Insurance Participants in Kolaka District".

\section{METHOD}

This type of research is a quantitative study, with a cross sectional study approach, which aims to determine the relationship between the independent variables (income, active cadres and perceptions of the quality of health services) and the dependent variable (compliance with paying dues) which is observed at the same time. (5). This research was conducted in Kolaka District, Kolaka Regency, Southeast Sulawesi Province. Research implementation until the preparation of the final report starting in December 2019 and finishing in August 2020. The population in this study were all 18293 independent national health insurance participants in Kolaka District. In this research, as many as 377 respondents were taken by means of proportional random sampling.

\section{RESULTS}

Table 1.Shows that of the 210 respondents whose income levels are in the low category, 143 respondents $(68.1 \%)$ are less obedient in paying the dues, 44 respondents $(21 \%)$ are not obedient in 
paying the national health insurance contributions on time and 23 respondents $(11 \%)$ comply on time in making payments for national health insurance contributions. Meanwhile, of the 167 respondents whose income level was in the high category, there were 60 respondents $(35.9 \%)$ who were not obedient in paying the dues, 35 respondents $(21 \%)$ were not obedient in paying the national health insurance contributions on time and 72 respondents $(43.1 \%)$ obey on time in paying the national health insurance contributions.Based on the results of statistical tests using the chi square test, at a $=0.05$ and $\mathrm{DF}=1$, the value of $\mathrm{X} 2$ is calculated $>\quad X 2$ table (56.060> 5.991), meaning that there is a significant relationship between income levels and compliance with national health insurance participant contributions. independently in Kolaka Regency.

Table 2. Shows that, of the 213 respondents who stated that their cadres were less active, 132 respondents (62\%) were less obedient in paying the dues, 43 respondents (20.2\%) were not compliant in paying the national health insurance contributions on time and 38 respondents (17.8\%) comply on time in making payments for the national health insurance contributions. Meanwhile, of the 164 respondents with good cadre activity, there were 71 respondents $(43.3 \%)$ who were less obedient in paying the dues, 36 respondents $(22 \%)$ were not obedient in paying the national health insurance contributions on time and 57 respondents $(34.8 \%)$ obey on time in paying the national

health insurance contributions.Based on the results of statistical tests using the chi square test, at $\mathrm{a}=0.05$ and $\mathrm{DF}=$ two, the value of $\mathrm{X} 2$ is calculated $>\mathrm{X} 2$ table (16.663> 5.991), which means that there is a significant relationship between the activeness of cadres and compliance with the national health insurance participant contributions. Independently in Kolaka Regency.

Table 3. Shows that, of the 177 respondents whose perceptions of health services were lacking, 126 respondents $(71.2 \%)$ were less obedient in paying contributions, 34 respondents $(19.2 \%)$ did not obey on time in paying health insurance contributions. nationwide and 17 respondents (9.6\%) comply on time in making payments for the national health insurance. Meanwhile, of the 200 respondents whose perceptions of the quality of health services were good, there were 77 respondents $(38.5 \%)$ who were less obedient in paying dues, 45 respondents $(22.5 \%)$ did not obey on time in making payments for national health insurance contributions and 78 respondents (39\%) comply on time in making payments for national health insurance contributions.Based on the results of statistical tests using the chi square test, at a $=0.05$ and $\mathrm{DF}=$ one, the value of $\mathrm{X} 2$ is calculated $>\quad X 2$ table (51.315> 5.991), meaning that there is a significant relationship between perceptions of health services and compliance with payment of contributions from insurance participants. Independent national health service in Kolaka Regency

\section{Table 1}

Relationship between Income Level and Contribution Payment Compliance to Participants of the Independent National Health Insurance in Kolaka District

\begin{tabular}{|c|c|c|c|c|c|c|c|c|c|}
\hline \multirow{3}{*}{ Income } & \multicolumn{6}{|c|}{ Contribution Payment Compliance } & & & \multirow{3}{*}{ Statistic test } \\
\hline & \multicolumn{2}{|c|}{$\begin{array}{c}\text { Less } \\
\text { obedient }\end{array}$} & \multicolumn{2}{|c|}{$\begin{array}{c}\text { Obedient } \\
\text { Not } \\
\text { Timely } \\
\end{array}$} & \multicolumn{2}{|c|}{$\begin{array}{l}\text { Obedient } \\
\text { on Time }\end{array}$} & \multicolumn{2}{|c|}{ total } & \\
\hline & $\mathbf{n}$ & $\%$ & $\mathbf{n}$ & $\%$ & $\mathbf{n}$ & $\%$ & $\mathbf{n}$ & $\%$ & \\
\hline Less & 143 & 68.1 & 44 & 21 & 23 & 11 & 210 & 100 & \\
\hline Well & 60 & 35.9 & 35 & 21 & 72 & 43.1 & 167 & 100 & $\begin{array}{l}X^{2} \text { table }=5.991\end{array}$ \\
\hline total & 203 & 53.8 & 79 & 21 & 95 & 25.2 & 377 & 100 & \\
\hline
\end{tabular}

Indonesian Journal Of Health Sciences Research and Development 
Bandu, J., Kamalia, L. O., \& Jayadipraja, E. A..

DOI: 10.36566/ijhsrd/Vol3.Iss1/63

https://ijhsrd.com/index.php/ijhsrd

e- ISSN: 2715-4718

Table 2

The Relationship between Cadre Activeness and Compliance with Contribution Payment to the Participants of the Independent National Health Insurance in

Kolaka District

\begin{tabular}{|c|c|c|c|c|c|c|c|c|c|}
\hline \multirow{3}{*}{$\begin{array}{c}\text { Cadre } \\
\text { Activity }\end{array}$} & \multicolumn{6}{|c|}{$\begin{array}{c}\text { Contribution Payment } \\
\text { Compliance }\end{array}$} & \multirow{2}{*}{\multicolumn{2}{|c|}{ total }} & \multirow[t]{3}{*}{ Statistic test } \\
\hline & \multicolumn{2}{|c|}{$\begin{array}{c}\text { Less } \\
\text { obedient }\end{array}$} & \multicolumn{2}{|c|}{$\begin{array}{c}\text { Obedient } \\
\text { Not } \\
\text { Timely } \\
\end{array}$} & \multicolumn{2}{|c|}{$\begin{array}{l}\text { Obedient } \\
\text { on Time }\end{array}$} & & & \\
\hline & $\mathbf{n}$ & $\%$ & $\mathbf{n}$ & $\%$ & $\mathbf{n}$ & $\%$ & $\mathbf{n}$ & $\%$ & \\
\hline Less & 132 & 62 & 43 & 20.2 & 38 & 17.8 & 213 & 100 & $X^{2} \operatorname{count}=16.663$ \\
\hline Well & 71 & 43.3 & 36 & 22 & 57 & 34.8 & 164 & 100 & $\mathrm{X}^{2}$ table $=5.991$ \\
\hline total & 203 & 53.8 & 79 & 21 & 95 & 25.2 & 377 & 100 & \\
\hline
\end{tabular}

Table 3

The Relationship between Perceptions of Health Services and Compliance with Contribution Payment to Participants of the Independent National Health Insurance in Kolaka District

\begin{tabular}{|c|c|c|c|c|c|c|c|c|c|}
\hline \multirow{3}{*}{$\begin{array}{c}\text { Perceptions } \\
\text { of Health } \\
\text { Care } \\
\text { Facilities }\end{array}$} & \multicolumn{6}{|c|}{ Contribution Payment Compliance } & & & \multirow{3}{*}{ Statistic test } \\
\hline & \multicolumn{2}{|c|}{$\begin{array}{c}\text { Less } \\
\text { obedient }\end{array}$} & \multicolumn{2}{|c|}{$\begin{array}{c}\text { Obedient } \\
\text { Not } \\
\text { Timely } \\
\end{array}$} & \multicolumn{2}{|c|}{$\begin{array}{l}\text { Obedient } \\
\text { on Time }\end{array}$} & \multicolumn{2}{|c|}{ total } & \\
\hline & $\mathbf{n}$ & $\%$ & $\mathbf{n}$ & $\%$ & $\mathbf{n}$ & $\%$ & $\mathbf{n}$ & $\%$ & \\
\hline Less & 126 & 71.2 & 34 & 19.2 & 17 & 9.6 & 177 & 100 & \\
\hline Well & 77 & 38.5 & 45 & 22.5 & 78 & 39 & 200 & 100 & $\mathrm{X}^{2}$ table $=5.991$ \\
\hline total & 203 & 53.8 & 79 & 21 & 95 & 25.2 & 377 & 100 & \\
\hline
\end{tabular}

\section{DISCUSSION}

Relationship between Income Level and Contribution Payment Compliance for Independent National Health Insurance Participants in Kolaka District

Income is income arising from community activities every month according to the minimum wage standard per capita income of the region (6). Income or income is also an additional economic capacity received or obtained from both Indonesia and outside Indonesia which can be used for consumption or to increase wealth. The income factor can be used as one of the reasons for the participants of the independent national health insurance contributions to not comply with their monthly payments. As stated by Nurmantu, who states that if a person works and can then earn money, then instinctively the money is first aimed at fulfilling one's own needs or basic needs and that of his family but at the same time if he has met certain conditions it arises. obligation to pay contributions which in turn result in conflicts between family interests or meet health insurance payments (7).

The results of this study indicate that, of the 210 respondents whose income levels are in the low category, 143 respondents $(68.1 \%)$ are less compliant in paying contributions; this is because participants still prioritize primary needs from health 
insurance needs. As a result, the fulfillment of secondary needs and health insurance needs has not been prioritized so that the contribution payments for the independent national health insurance are still in arrears. Most people pay independent national health insurance when they are sick, so that when they want to reuse the national health insurance facility, participants have to pay a number of bills that are increasing and sometimes exceeding medical costs.

The results of this study, if examined more deeply, the causes of respondents are in arrears in making contribution payments are also due to the large number of expenses such as food expenditures which are quite high starting from expenditure on rice, side dishes to crackers, non-food expenditures for purposes such as durable goods (kitchen utensils, cell phones ) purchased only when needed, while the largest non-food expenditures are payments for electricity, gas and water because of their regular monthly needs. Non-essential expenditure, the largest amount of expenditure is cigarettes and snacks. Many respondents are also married and have children so that the expenditure for children's snacks is quite high(8). This is in line with research conducted in DarulImarah District which shows that the results of the total expenditure on cigarette consumption and the amount of food consumption expenditure for the poor are inversely proportional, meaning that if the amount of cigarette consumption expenditure increases it will reduce the total expenditure on food consumption.(9).

In addition, of the 210 respondents whose income level was in the low category, there were also 44 respondents $(21 \%)$ who did not comply on time in making payments for national health insurance contributions and 23 respondents $(11 \%)$ were compliant on time in making payments for national health insurance contributions. Based on the results of the researchers' interviews with these respondents, it was found that these respondents had a history of catastrophic diseases which required them to continue to take medication at a health service center and incur substantial costs. This respondent argued that by regularly paying the National Health Insurance fee from the Social insurance administration organization, the respondent could still get health services that were more convenient than taking public patient facilities, which cost quite a lot.

Meanwhile, of the 167 respondents whose income level was in the high category, 60 respondents $(35.9 \%)$ were not obedient in making contribution payments. This is more due to other factors including the forgetting factor, the busy work factor because the national health insurance party does not have monthly notification to make contribution payments so that in this situation the community forgets to pay the independent national health insurance contributions.

In addition, people who have sufficient income but are not compliant are also due to the large number of community needs that must be fulfilled, for example the needs of schoolchildren, household needs etc. The independent national health insurance premium payment is quite burdensome because the national health insurance premium payment must be paid every month and in groups or together with other family members. Just imagine that every person who participates in the first class health facility (1) must pay a fee of IDR 150,000 per month. This is in line with the theory that the size of wealth can affect health consumption. For example, people with low incomes will meet the needs of goods first, after the need for goods is fulfilled will consume health. Factors that have a direct effect on income, for example, costs related to health services, increase the cost of health services. This situation reduces health consumption, because the increase in health costs will reduce the relative income, namely fixed income while health costs increase. This difference may occur due to differences in culture and beliefs about the importance of health. 
Another reason the respondent did not want to pay was that the card could be used, later if there is money or later if someone is sick, such as if the wife wants to give birth. Apart from that, the reasons why the respondents did not want to pay dues were, among others, lazy to pay. The cause of this laziness when analyzed further is due to the disappointment experienced by respondents in using the national health insurance card which is late in being served and is not even served by health services.

In addition, of the 167 respondents whose income level is in the high category, there are also 35 respondents $(21 \%)$ who are not compliant on time in making payments for national health insurance contributions and 72 respondents $(43.1 \%)$ are compliant on time in making payments for national health insurance contributions. This illustrates that a high level of income and has a middle to upper level of welfare have a high level of compliance in making National Health Insurance contributions. This is reinforced by the results of data analysis using the chi square test, at $\mathrm{a}=0.05$ and $\mathrm{df}=1$, the value of X2 is calculated> X2 table (56.060> 5.991), meaning that there is a significant relationship between income levels and compliance with participant contributions. Independent national health insurance in Kolaka Regency.

This research is in line with research conducted in Kota Solok which shows that the percentage level of independent participants in paying uranium for the national health insurance program is higher in the group of participants with high income levels $(39.6 \%)$ compared to the group of participants with low income levels $(19,5)$. $2 \%$ ), with the results of data analysis showing that there is a relationship between income levels and compliance with the national health insurance program premium payments $(\mathrm{p}=0.038)(10)$.

This research is also in line with research conducted in the Batailaiworu Health Center's working area which states that there is a relationship between income levels and compliance with dues payments to independent national health insurance participants, where the statistical test results obtained $p$ value $=0.023<a=0.05$. (11).

This research is also in accordance with the results of research conducted in Malang Regency, which shows that there is a relationship between income levels and the compliance of independent participants in paying dues. (12).

Independent participants with low income prioritize their income to meet routine daily living needs, such as food costs, education costs, electricity and water payments and other costs, while for health costs, independent participants tend not to prioritize because they are still in a healthy condition. On the other hand, independent participants with high income, apart from being able to allocate their income for daily needs, are also able to pay health costs so that they can make regular monthly payments.(10).

Likewise with the influence of income with the regularity of the community in paying National Health Insurance contributions. A person's income plays an important role in increasing one's awareness of regularity in paying National Health Insurance contributions. Low income can reduce the regularity of the community in paying National Health Insurance contributions because there are still many needs that must be met by the family so that no income allocation is used by participants to pay these contributions. It is different with those who have high income and have middle and upper welfare levels who have a high level of regularity in paying the National Health Insurance contributions.(13).

The Relationship between Perceptions of Health Services and Compliance with the Participants' Payment Compliance with the National Independent Health Insurance in Kolaka District

Perception is the process of organizing; interpreting the stimuli received by the individual so that it is something 
meaningful and is an activity that is integrated in the individual. (14). Patients' perceptions will be influenced by personality, culture, education, previous events, both positive and negative, which may often be encountered when receiving services at the hospital. Patients' perceptions of service quality are influenced by expectations of the desired service. Expectations are shaped by what consumers hear from other consumers by word of mouth, patient needs, past experiences and the influence of external communication. Services received from existing expectations affect consumers on service quality(15). Perception is usually to express about the experience of an object or event where it is obtained through information and relationships so as to provide meaning or meaning in the form of actions or responses from individuals.(16).

The results showed that, of the 177 respondents who had poor perceptions of health services, 126 respondents (71.2\%) were less obedient in paying contributions. This illustrates that the low perception of participants on the quality of health services received will have an impact on the willingness of participants to make payments. This is when examined further because these participants feel less satisfied with the services provided to patients with the national independent health insurance because in terms of services it is rather long. Services require a long and convoluted process in terms of health services. Because some of the first level health facilities, in this case the health center in providing patient referrals to the advanced level health facilities, in this case the hospital or specialist doctor are rather complicated and seem to be delayed. This makes these participants feel that health services are not good enough, so some of them are in arrears just because of problems like this. Apart from that, not all health facilities or health services that are covered by the national health insurance coverage also influence these participants not to make contribution payments. This can be seen from the respondents' answers, only $48 \%$ of respondents are optimistic that they will not be disappointed by the services received by using the national health insurance facility. That is why some of them are in arrears just because of problems like this. In addition, not all health facilities or health services that are covered by the national health insurance coverage also influence these participants not to make contribution payments. This can be seen from the respondents' answers, only $48 \%$ of respondents are optimistic that they will not be disappointed by the services received by using the national health insurance facility. That is why some of them are in arrears just because of problems like this. Apart from that, not all health facilities or health services that are covered by the national health insurance coverage also influence these participants not to make contribution payments. This can be seen from the respondents' answers, only $48 \%$ of respondents are optimistic that they will not be disappointed by the services received using the national health insurance facility.

This can also cause low public awareness to buy or want to become a health insurance participant. From research, it is also known that there are some people who do not care about the risks they face and they take or accept a risk as it is to their health. People who behave in this way are called risk takers. If everyone acted as a risk taker, then the insurance business would never exist. Conversely, if a person acts as a risk averter, he will try to avoid, reduce, or transfer risks that may occur to him. If many people are risk averse, the demand for health insurance business will grow.

This is also in line with the theory, which states that perceptions of the quality of health services greatly influence participant satisfaction, which have an impact on participant compliance in making payments. The ability to perform services according to what was promised immediately, accurately, and satisfactorily has an impact on 
participant satisfaction and participant compliance in making payments(17).

In addition, of the 177 respondents whose perceptions were less of health services, there were 34 respondents $(19.2 \%)$ who did not comply on time in paying the national health insurance contributions and 17 respondents $(9.6 \%)$ complied on time in making payments for national health insurance contributions. The results of the interview with the respondent were known because this respondent was forced to make payments because the respondent was suffering from a disease, which required the respondent to continue to seek treatment at the hospital, even though the services received were not satisfactory and not all were covered by the national health insurance. In addition, respondents also get support and motivation from family members who understand the rules for obtaining health insurance.

Meanwhile, of the 200 respondents whose perceptions of the quality of health services were good, 77 respondents $(38.5 \%)$ did not comply with the payment of contributions. According to the researcher interview, it was known that the cause of this respondent was still in arrears even though he had a good perception of the quality of health services received was another factor, namely the amount of contributions that were considered quite burdensome. This is when examined more deeply because the wages or income received are still below the Provincial Minimum Wage each month. Moreover, the payment of national health insurance contributions must be paid every month. In addition, when payments are made in one (1) household that must be paid, not all family members can be paid individually in the family.

In addition, there is still a wrong perception of the problem of national health insurance, namely that national health insurance is only used when sick and when not sick, and there is no need to pay national health insurance contributions independently. Respondents also felt that they would be disadvantaged if they made regular payments but did not use health service facilities through the national health insurance. As a result, there were arrears that were greater than the costs that had to be paid when receiving medical treatment through public patients so that these respondents no longer wanted to make payments.

Confidence about the losses that are obtained if you become a participant of the National Health Insurance, namely getting slow / long health services, receiving incomplete health services, being served less kindly, still paying or there are additional costs when sick and getting uncomfortable service facilities. This requires a follow-up in the form of an increase in service speed followed by friendliness of officers and the comfort of treatment facilities, which are expected to be felt by the community if they become participants in the National Health Insurance. If this can be applied in the field, then the belief about losses from the service side can be reduced and in the end, it is hoped that it can increase the intention to become a participant in the National Health Insurance. other than that,(18).

In addition, of the 200 respondents, whose perceptions of the quality of health services were good, there were also 45 respondents $(22.5 \%)$ who did not comply on time in paying the national health insurance contributions and 78 respondents (39\%) complied on time in making payments for national health insurance contributions. This illustrates that good public perception will increase public awareness of the importance of making independent national health insurance premium payments. If examined further, this is because they feel that they only pay a fee of only IDR. 80.000, - each month you can experience optimal health facilities such as doing free cataract eye surgery and others. These results are also reinforced by the results of data analysis using the chi square test, at $\mathrm{a}=0.05$ and $\mathrm{DF}$ $=1$, 
This research is in line with research conducted on the independent participants of the national health insurance program in Kota Solok, where the results obtained were that there was a significant relationship between the level of perceptions of health services and perceptions of risk and compliance with the payment of dues for participants in the national health insurance program in Solok City. (19).

This research is also in line with research conducted in the Abeli Puskesmas Kendari City, which shows that there is a strong enough between perceptions and arrears in the payment of dues from social insurance administration organization, where a value is obtained (p-value $=0,000)$. (20).

The level of needs at the lower level has been met, so this need will give rise to the need to meet higher needs. So that when the National Health Insurance is made as a priority need by the community, the community will regularly pay the National Health Insurance contribution(21). The willingness of a person to pay contributions is greatly influenced by the motivation of each person. A person's motivation can arise due to various things, both positive, namely motivation that can be beneficial and negative, namely motivation that can provide losses(22).

\section{Relationship between Cadres and Participant Payment Compliance with Independent National Health Insurance in Kolaka District}

Cadre is a person or community member who collaborates as a partner of a health social security provider based on a partnership relationship that carries out some of the functions of the social insurance administration organization in a certain area that has the capacity according to certain criteria and is recruited by the social insurance administration organization. Cadres are people who have the capacity according to the criteria of the social insurance administration organization to carry out certain functions, namely socialization (social marketing) functions, recruitment of participants, reminders and collection of contributions (23).

Participants from the informal worker sector have unique and diverse background characteristics with a large population, which is spread across various remote areas in Indonesia. In its current condition, community participation is very much needed in supporting the success of the national health insurance program, so the social insurance administration organization presents a new mechanism in this case community empowerment with the aim of expanding participation and finding the right contribution collection method for various community characters(23).

The results of this study indicate that, of the 213 respondents who stated that the cadres were less active, 132 respondents $(62 \%)$ were less obedient in paying contributions. Based on the results of the researchers' interviews, it is known that so far cadres have rarely provided information related to national health insurance or social insurance administration organization, so far cadres have only been active in collecting national health insurance contributions only. The lack of active cadres resulted in the lack of quality information obtained by participants regarding the national health insurance program. Whereas the function of cadres is not only to collect contributions, but also as social marketing, participation function, information provider function and complaint receiver. With the cadres, it is hoped will optimize socialization, education, as well as a reminder and collection of contributions.

This in addition, as can be seen from the respondents' answers, only $43 \%$ stated that they had been given information by cadres regarding participants being able to adjust their fees according to their ability to pay. Even though this information is important information that must be conveyed to participants so that participants can pay dues smoothly and avoid an inactive card due to delinquency in dues that do not match 
their income. Given the information provided will affect a person's knowledge to behave(24).

From the research results, it is also known that only $52 \%$ of respondents stated that they received information regarding the increase in national health insurance contributions from cadres. Yet according to Regulations resident umber 64 year 2020a about changei Secondi Oni Regulationsi Presidenti Numberi82 year 2018 about Guarantee Health. Based on beleid that,duesi members hipii ndependently classi Iiwillir ideifrom IDR 80 thousandi Becomes iIDR150ithousandiperiparticipants. While dues independently class from IDR 51 thousand Becomes IDR100ithousand periparticipantsiperimonth.iWhileiduesiInde pendenticlassiIIlirideifrom iIDR25,500 periparticipantsiperimonthiBecomes iIDR35 thousandiperiparticipantsiperimonth

IDR16,500 peripersoni perimonthiget paidibyigovernmenticenteriasi helpiduesitoi participantsi Non-Wage WorkersiandiparticipantsiNot Workers. However,iparticipantsiindependentlyiclassiII Iistillicanienjoyiratesilong IDR25,500 periparticipantsiperimonthibecauseithere sihelpisubsidyifromigovernment.iParticipant siclassithisinewipayifulliduesiamounting to iIDR35ithousandistart iliJanuary i2021(23).

And of the 213 respondents who stated that the cadres were less active, there were also 43 respondents $(20.2 \%)$ who did not comply on time in making payments for national health insurance contributions and 38 respondents $(17.8 \%)$ were compliant on time in making payments for national health insurance contributions. . According to interviews, researchers with several respondents stated that they were forced to make payments because the respondent suffered from a disease which required the respondent to continue to seek treatment at the hospital, although the services received were not satisfactory and not all were covered by the national health insurance.

Meanwhile, out of 164 respondents with good cadre activity, 71 respondents
$(43.3 \%)$ were less obedient in paying contributions. From the interview, it was found that the cadres did not have much experience and were less well-known to the participants, so they lacked communication during home visits.

Another reason is because the participants in the national health insurance independently registered because they were already sick. so they immediately register as participants in the independent national health insurance. after they do not receive services at the hospital or puskesmas, participants do not continue to pay the independent national health insurance contributions. Besides that, the independent national health insurance participants feel burdened by their finances because the benefits they pay are not being felt now because they are not sick yet. This was revealed by some respondents themselves that they felt that they had suffered a loss because after paying contributions from the social security administering body, the benefits would not be felt now.

And of the 164 respondents with good cadre activity, there were also 36 respondents $(22 \%)$ who did not comply on time in making payments for national health insurance contributions and 57 respondents (34.8\%) were compliant on time in making payments for national health insurance contributions. In this study, the guidance provided by the cadres was active and evenly supported by the factor of cadre education, namely Senior High Schools. According to theory, a higher level of education will have better insight and better skills so that it will be better able to provide guidance to the community.

Apart from that, the positive things that the community feels from the social insurance administration organization are expressed by some respondents that when they are sick at a very high cost, it is free from the facilities provided by the social insurance administration organization and this makes some participants feel comfortable for the national health insurance 
independently. so the motivation to register as a participant in the independent national health insurance is because the facilities offered by some of the social insurance administration organization attract participants.

This increases the motivation of the residents because of the existence of some of the facilities provided by the social insurance administration organization to participants. When registering for independent national health insurance, participants feel that it is facilitated by registration because services at the office of the Kolaka Social insurance administration organization are carried out with good services so that these participants are enthusiastic about registering themselves and making payments. There are also some people who think that registering themselves is a form of guarding themselves from things related to illnesses that occur at certain times. Information from friends to friends, TV media, and print media also greatly influences and motivates some people to register themselves as participants in the independent national health insurance.

This is in accordance with the theory which states that motivation is an interaction between behavior and the environment so that it can increase, decrease or maintain behavior. Motivation also means the impulse from within humans to act or behave(25). This is reinforced by the results of data analysis using the chi square test, at $\mathrm{a}=0.05$ and $\mathrm{df}=1$, the value of $\mathrm{X}^{2}$ is calculated $>\mathrm{X}^{2}$ table (16.663> 5.991), which means that there is a significant relationship between the activeness of cadres and compliance with participant contributions. independent national health insurance in Kolaka Regency.

Cadres have a social marketing function that aims to change people's behavior to register as non-Wage Workers and pay dues regularly. Periodically, participants and prospective participants in the national health insurance will be given education through visits so that they are orderly in carrying out their obligation to pay contributions and understand the importance of having National Health Insurance. In addition, Kader also functions as a reminder and collector of contributions, both active and in arrears for Non-Wage Recipient Workers. Cadres also work as Online Bank Payment Point agents, so that if participants want to make monthly dues payments, they can go directly to these Cadres.(26).

The cadre program is also inseparable from the cooperation and support of all parties, especially 4 state-owned banks as partners for social insurance administration organization, stakeholders, local governments, local village officials and other partners who tirelessly continue to support the social insurance administration organization in realizing quality and sustainable National Health Insurance for all Indonesian residents (27).

\section{CONCLUSION}

There is a relationship between income levels, activeness of cadres and perceptions of health services with compliance with payment of dues to independent national health insurance participants in the Kolakadistrict. Therefore, it is advisable for social insurance administration organization to carry out strategies in an effort to improve the regularity or compliance of independent national health insurance participants in paying dues, such as events that the social security administering body goes to campus, participate actively in social organization activities. , increasing the number of cadres, actively socializing the national health insurance program through social media.

\section{REFERENCES}

1. Ministry of Health of Republic of Indonesia. Indonesia Health Profile 2019. Jakarta: Ministry of Health of the Republic of Indonesia. 2020.

2. Kolaka District Health Office. Health Profile of Kolaka Regency in 2018. Dinkese district Kolaka: Kolaka. 2020. 
3. BPJS Health. Profile of the BPJS Health Social Security Administering Body: Jakarta. 2020.

4. Pratiwi AN. Factors Affecting Regularity of Contribution Paying to National Health Insurance (JKN) Participants in the Independent Participant Category (Case Study of Inpatients at $d r$. Soebandi Hospital, Jember Regency). 2016.

5. Ditta T. Predisposing, Supporting, and Driving Factors Affecting Behavior Towards Payment Compliance of NonWage Recipient Workers (Pbpu) Participants in Pacitan Regency in 2018: Stikes Bhakti Husada Mulia; 2018 .

6. NWAP Citizen. Perceptions of Mandiri National Health Insurance Participants Regarding the Policy for Family Virtual Account Fee Payment in Denpasar City in 2017. Public Health Study Program, Faculty of Medicine, Udayana University, Denpasar. 2017.

7. Nurul A. Factors Related to Willingness to Pay National Health Insurance Contribution to Non-Wage Workers in the Work Area of the Payakumbuh Public Health Center in 2015: Andalas University; 2015.

8. Notoatmodjo S. Health Research Methods. Jakarta Rineka Cipta. 2014.

9. Siregar PN. Analysis of Irregularity Factors in Paying Contribution for Bpjs Mandiri Participants in Rantau Utara District, Labuhanbatu Regency. Helvetia Institute of Health. 2018.

10. Nurmantu S. Introduction to taxation. Jakarta: Granit CPEd, editor: Yayasan Obor Indonesia; 2013.

11. Marzuki DS, Abadi MY, Darmawansyah D, Arifin MA, Rahmadani S, Al Fajrin M. Analysis of Ability to Pay and Willingness to Pay PBPU Participants Who Arreated JKN
Contribution in Tamalate District, Makassar City. Journal of Health Management at Dr. Soetomo Hospital Foundation. 2019; 5 (2): 102-13.

12. Satria D. Correlation of Total Cigarette Consumption Expenditures with Total Food Consumption Expenditures for the Poor (Case Study of Darul Imarah District, Aceh Besar District). Development Economics Student Scientific Journal. 2017; 2 (1): 84-93.

13. Wulandari A, Syah NA, Ernawati T. Factors Influencing Compliance of Independent Participants in Payment of National Health Insurance Program Contribution in Solok City. Andalas Health Journal. 2020; 9 (1): 7-17.

14. Rismawati L, Jufri N. Factors Related With Compliance Paying of BPJS Mandiri Insurance / Contribution in the Working Area of Batalaiworu Public Health Center In 2017 '. Public Health Student Scientific Journal. 2017; 2 (8): 1-10.

15. Izza N. Independent Participant Collective Payment System with Membership Status and BPJS Health Contribution Payment Compliance in Malan Regencyg. Health Systems Research Bulletin. 2019; 22 (1): 44-53.

16. BPJS Health. Info on BPJS Health edition XXII. Jakarta: BPJS Health. 2016.

17. Syaputra AD. Relationship between BPJS Health Service Quality and Patient Satisfaction in Class I Inpatient Installation at Sekayu Regional General Hospital in 2015.Journal of Nursing Palembang: Musi Banyuasin Regency Government Nursing Academy. 2015.

18. Simanjuntak SO. The Effect of Service Quality on Consumer Loyalty at PT. Eka Mega Adika Medan. 2019.

19. Rifa'i A. Analysis of the Influence of Perception and Behavior of Jamiah 
Pondok Pesulukan Tarekat Agung Tulungagung on Saving Interest in Islamic Banking with Attitude as a Moderating Variable. 2019.

20. Puspitasari W, Hasbie NF. The Effect of Service Quality on the Satisfaction Level of Outpatient Bpjs Patients at Pertamina Bintang Amin Hospital in Bandar Lampung in 2016.Journal of Medical and Health Sciences. 2017; 4 (2).

21. Pakki TR. The Effect of Service Quality on Income, which is moderated by LOS (Length Of Stay) at RS. Dr. Lung HA Rotinsulu Bandung: UNPAS; 2016.

22. Ayu W. Compliance Analysis of Independent Participants in the Payment of National Health Insurance Program Contribution in Solok City. Andalas University Public Health Journal. 2019.

23. Hasyim A, Idrus M, Rizky S. Miracle Journal Of Public Health. 2019; 2 (1): 1-9.

24. Sondari A. Satisfaction Analysis of Outpatient Participants in National Health Insurance (Jkn) at the Regional General Hospital (Rsud) in Brebes Regency in 2015. Semarang State University. 2015.

25. Tiaraningrum R. Descriptive Study of Motivation and Personal Reference of Jkn Independent Participants in the Highest Areas in Mojosongo Village, Surakarta City. Muhammadiyah Surakarta university. 2014.

26. Mangidi MAGT, Sunarsih S, Jayadipraja EA. The Effect of Triggering on Larva Free Rate (Abj) in Rahandouna Village, Kendari City.Alsihah: The Public Health Science Journal. 2019; 11 (2).

27. Rahmi N. The Influence of Work Environment on Employee Work Motivation at the Boalemo District
Health Office. Mala'bi: Journal of Economic Management STIE Yapman Majene. 2020; 2 (2): 65-84.

28. Aidha CN, Chrisnahutama A. Deficit of National Health Insurance (JKN) Suggestions for Alternative Sustainable Funding. 2020.

29. Djamhari EA, Aidha CN, Ramdlaningrum H, Kurniawan DW, Fanggidae SJ, Herawati $\mathrm{H}$, et al. Deficit of National Health Insurance $(J K N)$ : Why and How to Solve It? PRAKARSA Association, 2020. 